\title{
Ekuivalen Tarif dan Determinan Impor Jasa Telekomunikasi di Negara APEC
}

\author{
Nisrina*, Widyastutik \\ Departemen Ilmu Ekonomi,Fakultas Ekonomi dan Manajemen, Institut Pertanian Bogor \\ Jalan Agatis, Kampus Darmaga, Bogor 16680, Indonesia \\ *Korespondensi: widyastutik_ipb@yahoo.com
}

[diterima: Febuari 2019- revisi: April 2019-diterbitkan daring: Juli 2019]

\begin{abstract}
ABSTRAK
APEC (Asia-Pasific Economic Cooporation) merupakan kerjasama ekonomi antara 21 negara anggota yang dibentuk pada tahun 1989 dengan tujuan memperkuat pertumbuhan ekonomi kawasan. Perdagangan di sektor jasa merupakan salah satu fokus ruang lingkup kerjasama ekonomi APEC. Salah satu sektor jasa yang memiliki peran penting adalah sektor telekomunikasi, yang merupakan " $a$ set backbone" dari sektor jasa. Penelitian ini bertujuan untuk menganalisis faktor-faktor yang memengaruhi impor jasa telekomunikasi serta mengestimasi ekuivalen tarif untuk melihat seberapa besar hambatan perdagangan jasa pada masing-masing negara APEC. Metode penelitian yang digunakan adalah gravity model dengan regresi data panel. Hasil penelitian menunjukkan faktor-faktor yang signifikan memengaruhi nilai impor jasa telekomunikasi di negara APEC adalah PDB riil, jarak, kesamaan bahasa, dan kesamaan sejarah kolonial. PDB riil negara importir maupun eksportir berpengaruh positif begitupun dengan bahasa dan sejarah kolonial. Sementara itu, jarak berpengaruh negatif terhadap nilai impor jasa telekomunikasi di negara APEC. Estimasi ekuivalen tarif menunjukan bahwa Meksiko, Filipina, Peru dan Selandia Baru merupakan negara yang memilki hambatan perdagangan paling tinggi, sedangkan Singapura memiliki rata-rata nilai ekuivalen tarif terendah diantara negara-negara APEC.
\end{abstract}

Kata kunci: Perdagangan Jasa, Jasa Telekomunikasi, Hambatan Perdagangan, Graviy Model, APEC

\section{ABSTRACT}

APEC (Asia-Pacific Economic Co-operation) is an economic cooperation among 21 member countries that was formed in 1989 with the aim of strengthening the economic growth in the region. Trade in services is one of the focuses in the APEC cooperation. One of the service sectors that has an important role as a set backbone in the economy is the telecommunication sector. This study aims to analyze the determinants of the import in the telecommunications services sector and estimate the tariff equivalent in each APEC country by using panel data model. The results show that the factors that significantly influenced the import value of telecommunications services in APEC countries are real GDP, distance, common language, and similarity in colonial history. The real GDP of importing and exporting countries has a positive impact on import, as well as the language and colonial history. Meanwhile, distance has a negative effect on the value of imports of telecommunications services in APEC countries. Estimated tariff equivalents suggest that Mexico, the Philippines, Peru and New Zealand are the countries with the highest trade barriers, while Singapore has the lowest average equivalent value among APEC countries.

Keywords : Trade in Services, Telecommunications, Trade Barriers, Gravity Model, APEC JEL Classification: F13, F14, C01 


\section{PENDAHULUAN}

\section{Latar Belakang}

Integrasi ekonomi yang dibentuk dari sebuah kawasan bertujuan untuk mengurangi atau menghilangkan hambatan serta meningkatkan kinerja perdagangan pada masing-masing anggota. Salah satu perkembangan integrasi ekonomi yang terjadi adalah APEC (Asia-Pasific Economic Cooporation) yang telah dibentuk pada tahun 1989 dengan tujuan memperkuat pertumbuhan ekonomi kawasan sehingga dapat mengembangkan dan memprediksikan kebutuhan-kebutuhan kawasan dalam konteks multilateral di kawasan Asia Pasifik. Terdapat 21 negara yang bergabung dalam keanggotaan APEC yang terdiri dari Australia, Brunei Darussalam, Kanada, Chile, China, Hong Kong, Indonesia, Jepang Korea, Malaysia, Meksiko, PNG, Peru, Filipina, Rusia, Singapura, Taiwan, Thailand, Amerika Serikat, dan Vietnam. Forum APEC memiliki 40 persen populasi, 54 persen
PDB dan 44 persen perdagangan dunia tergabung untuk mengupayakan perumusan strategi pembangunan di Asia-Pasifik (Setiawan 2011).

Kerjasama APEC memiliki ruang lingkup yang luas khususnya perdagangan beberapa sektor salah satunya ialah sektor jasa (trade in services). Sektor jasa memiliki peran penting terlihat dari besarnya nilai tambah yang diberikan oleh sektor jasa terhadap PDB dunia maupun anggota negara APEC. Seperti yang ditunjukan pada Gambar 1 nilai tambah dari sektor jasa lebih dari 60 persen pada tahun 2011 di dunia dan negara APEC. Bahkan untuk beberapa negara maju seperti USA, Singapura, Jepang, dan Hongkong sektor jasa memiliki nilai tambah lebih dari 70 persen pada tahun 2011. Jika suatu negara dengan ekonomi yang maju maka akan mencapai tingkat yang tinggi terhadap persentase dari aktivitas ekonomi yang mulai bergeser dari industri ke sektor jasa (services) atas respon pertumbuhan ekonomi (Hayami dan Godo 2005).

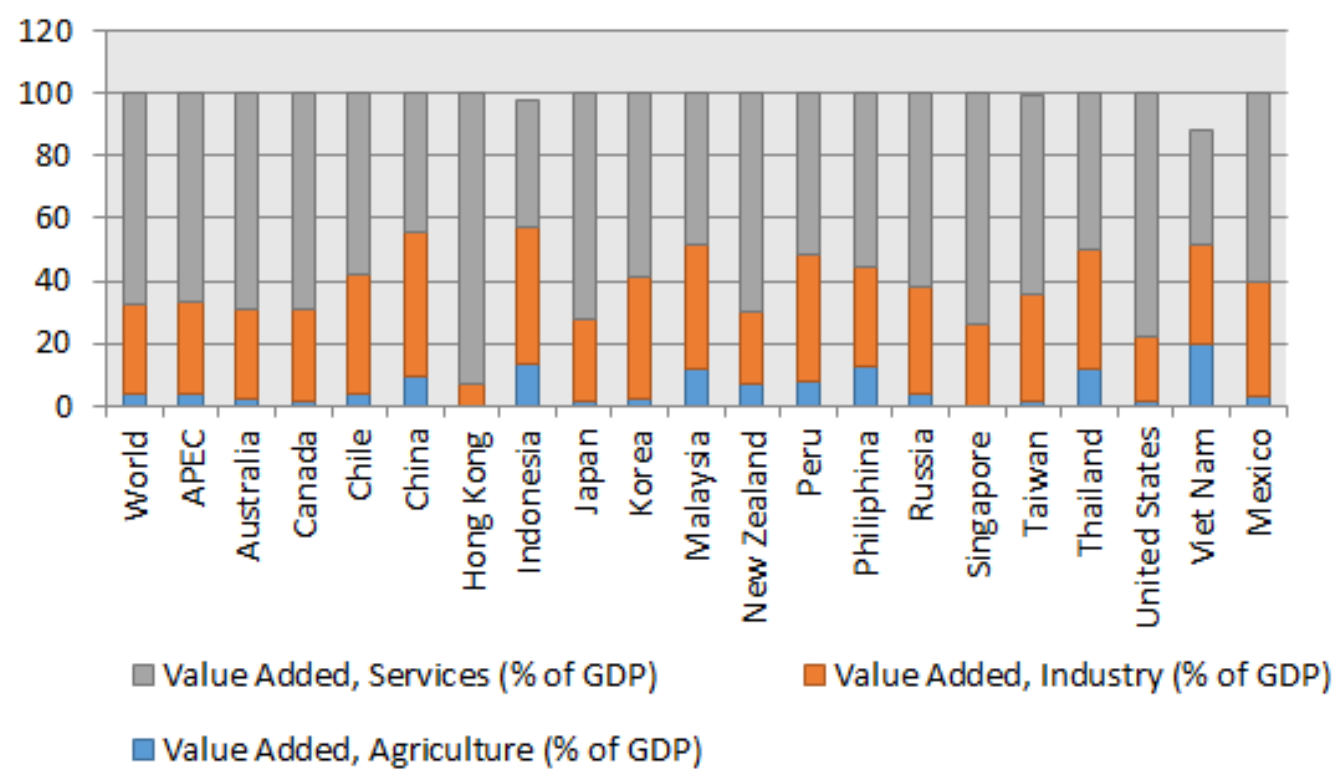

Sumber : APEC Statistik, 2011

Gambar 1. Peranan sektor jasa terhadap perekonomian

Peran sektor jasa menjadi semakin penting ketika terjadi peningkatan pada perdagangan barang. Sektor jasa sebagai input dalam proses produksi sektor pengolahan (servicification). Seperti yang di tunjukan pada Gambar 2, aktivitas ekspor dan impor mengalami peningkatan. Peningkatan impor lebih tinggi dibandingkan dengan peningkatan ekspor.
Perdagangan jasa di negara APEC masih didominasi oleh impor dengan pertumbuhan antara 0.5 persen hingga 0.13 persen selain pada tahun 2008 yang mengalami penurunan akibat pasca krisis global. Impor merupakan cermin kedaulatan ekonomi bagi suatu negara. Alasan suatu negara melakukan impor yaitu mengalami defisiensi (kekurangan/kegagalan) dalam 
memproduksi barang atau jasa bagi masyarakatnya (Atmadji, 2009). Pentingnya jasa sebagai input dalam proses produksi pengolahan perlu disikapi dengan kebijakan yang tepat.
Kebijakan yang tidak tepat terhadap impor jasa menyebabkan output sektor jasa menjadi mahal sehingga berdampak pada harga sektor yang menggunakan jasa sebagai inputnya.

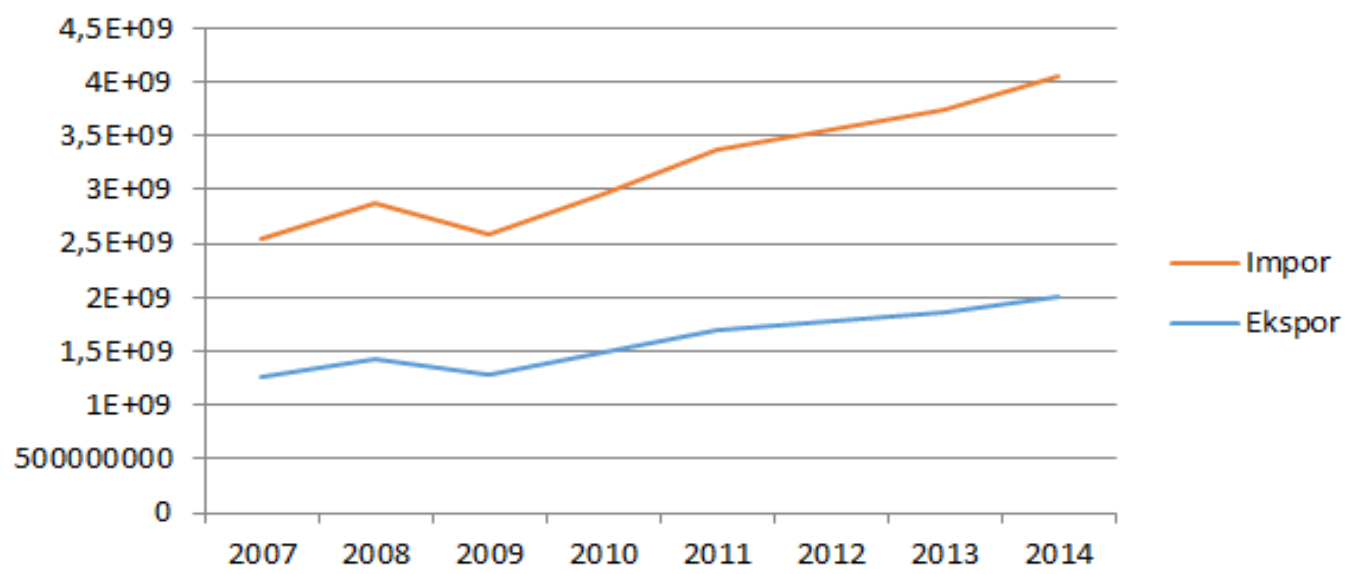

Sumber : Trademap database, 2017 (diolah)

Gambar 2. Perkembangan perdagangan jasa di negara APEC tahun 2007-2014.

Salah satu sektor jasa yang sarat dengan kebijakan adalah sektor jasa telekomunikasi. Kebijakan yang tidak layak akan menjadi hambatan dalam perdagangan jasa telekomunikasi. Padahal menurut Sapir (1988) jasa telekomunikasi memiliki peranan penting pada hampir seluruh bentuk pelayanan melalui penyediaan infrastruktur perdagangan jasa internasional. Hambatan perdagangan yang tinggi akan memengaruhi kinerja perdagangan. Kinerja perdagangan dapat dilihat dari besaran nilai impor. Nilai rasio impor jasa telekomunikasi terhadap total impor jasa di negara APEC relatif rendah seperti yang ditunjukan pada Gambar 3, yaitu dibawah 8 persen. Studi Lee Chun et al 2011 menunjukkan bahwa walaupun terdapat deregulasi terhadap kebijakan domestic, masih ditemukan adanya pembatasan serta hambatan masuk yang tinggi karena pencapaian skala ekonomi dan nilai sunk cost yang besar khususnya di jaringan lokal telekomunikasi. United States merupakan salah satu negara APEC yang memiliki nilai tertinggi yaitu 7.52 persen sementara Mexico memiliki nilai terendah dengan 0.37 persen.

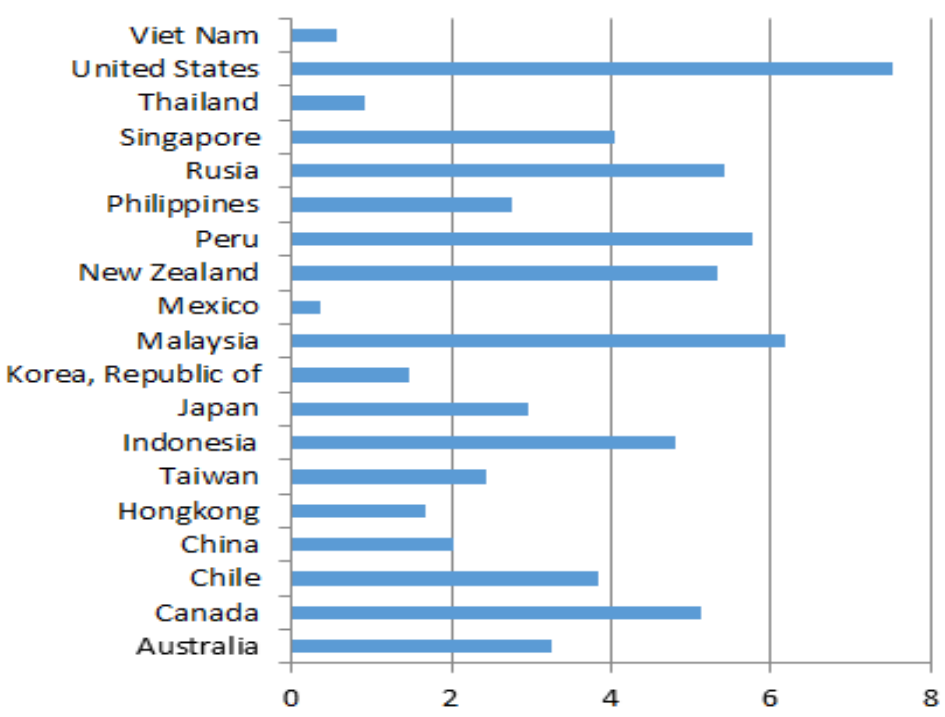

telekomunikasi

Sumber : UNCTAD 2017 (diolah)

Gambar 3. Rasio jasa telekomunikasi terhadap total impor jasa di negara APEC tahun 2014. 
Layanan jasa telekomunikasi memiliki berbagai bentuk yang merupakan penunjang bagi sektor lainnya. Beberapa bentuk layanan jasa telekomunikasi adalah public telecommunication transport services dan public telecommunication transport network. Pemenuhan kebutuhan akan sektor jasa telekomunikasi sebagai penunjang aktivitas di berbagai sektor diantaranya melalui impor jasa telekomunikasi. Di sisi lain untuk melindungi pasar domestik dengan terbukanya peluang impor setiap negara menerapkan hambatan perdagangan. Hambatan perdagangan di sektor jasa berbeda dengan sektor barang yaitu melalui hambatan non tarif yang berupa lisensi, syarat ijin tinggal, persyaratan sertifikasi bagi penyedia jasa asing dan pengaturan investasi asing. Terkait dengan hal tersebut, penting dilakukan penelitian mengenai faktor yang memengaruhi impor jasa telekomunikasi dan estimasi besaran hambatan perdagangan di sektor jasa telekomunikasi di lingkup APEC.

\section{Rumusan Masalah}

Karakterisktik perdagangan jasa berbeda dengan perdagangan barang. Pada umumnya hambatan perdagangan pada barang berupa tarif, sedangkan perdagangan sektor jasa dalam bentuk non tariff. Beberapa sektor jasa bersifat dapat diraba (tangible). Namun hampir sebagian besar sektor jasa tidak dapat diraba (intangible) dan tidak dikenakan tarif. Sektor jasa tidak diproduksi dan disimpan untuk kemudian dikonsumsi. Produksi dan konsumsi dilakukan secara simultan (Stern dan Hoekman 1988). Hambatan pada sektor jasa berupa restriksi terhadap interaksi antara produsen dan konsumen yang mengharuskan kehadiran kedua belah pihak atau sering disebut nature of service transaction. Selain itu hambatan sektor jasa berupa regulasi serta kontrol yang besar pada perdagangan jasa untuk menghindari adanya kegagalan pasar. Hal ini menyebabkan sulitnya mendeteksi hambatanhambatan yang ada di perdagangan sektor jasa karena berupa peraturan-peraturan.

Sektor jasa telekomunikasi semakin dibutuhkan seiring meningkatnya aktivitas sektor barang maupun jasa lainnya yang menggunakan layanan telekomunikasi. Namun keterbukaan sektor jasa telekomunikasi dapat menimbulkan dampak positif dan negatif terhadap sektor jasa telekomunikasi domestik. Oleh sebab itu regulasi atas hambatan perdagangan jasa telekomunikasi selalu dikaji sesuai kebutuhan masing-masing negara anggota APEC agar mengurangi dampak negatif yang ditimbulkan. Pengurangan hambatan perdagangan di sektor jasa telah disepakati pada General Agreement Trade in Services (GATS) serta melalui komitmen pada masing-masing FTA antar negara (Kemendag 2012). GATS menjadi aturan dasar dalam peraturan kebijakan perdagangan jasa telekomunikasi yang dilakukan antar anggota APEC melalui APEC Telecommunications and Information Working Group (APEC TEL WG) meetings. Oleh karena itu, kinerja perdagangan khususnya pada impor jasa telekomunikasi dipengaruhi oleh banyak faktor ekonomi dan non ekonomi serta adanya penerapan hambatan-hambatan disetiap negaranegara APEC.

Berdasarkan latar belakang yang telah diuraikan tersebut, penelitian ini akan menganalisis :

1. Faktor-faktor yang memengaruhi impor jasa telekomunikasi pada negara-negara anggota APEC?

2. Seberapa besar hambatan perdagangan pada impor jasa telekomunikasi negara-negara anggota APEC?

\section{Tujuan Penelitian}

Berdasarkan latar belakang dan rumusan masalah diatas, maka tujuan penelitian ini adalah :

1. Menganalisis faktor-faktor yang memengaruhi impor jasa telekomunikasi pada negara-negara anggota APEC.

2. Menghitung ekuivalen tarif impor jasa telekomunikasi negara-negara anggota APEC.

\section{METODOLOGI PENELITIAN}

Data yang digunakan dalam penelitian ini adalah data sekunder berupa data panel yaitu gabungan data deret waktu (time series) dan data deret lintang (cross section). Data yang digunakan terdiri dari data PDB riil, jarak geografis, nilai impor jasa telekomunikasi, dummy bahasa (comlang etno), dan dummy sejarah kolonial (common colony). Data deret waktu dalam penelitian ini adalah 2001, 2004, 2007, dan 2011. Data deret lintang (cross section) 
terdiri dari 19 negara anggota APEC, yang terdiri dari Australia, Kanada, Chili, China, Hongkong, Indonesia, Malaysia, Meksiko, Thailand, Vietnam, Taiwan (Chinese Taipe), Amerika Serikat, Peru, Jepang, Korea, New Zealand, Rusia, Singapura, dan Philipina.

\section{Metode Analisis}

Metode analisis yang digunakan dalam penelitian ini adalah metode kuantitatif berupa analisis regresi data panel dengan gravity model yang digunakan untuk menganalisis faktor-faktor yang memengaruhi nilai impor jasa telekomunikasi pada negara APEC. Tinbergen (1962) pertama kali menerapkan model ini untuk meneliti aliran perdagangan internasional. Seiring berkembangnya waktu penelitian menggunakan gravity model mengalami beberapa modifikasi, seperti nilai impor jasa telekomunikasi yang dijelaskan oleh PDB riil negara importir dan eksportir, jarak geografis antar kedua negara, dummy kesamaan bahasa, dan dummy kesamaan sejarah kolonial. Dalam penelitian persamaan gravity model yang digunakan adalah sebagai berikut:

$$
\begin{aligned}
L_{L N C M N}= & \alpha_{0}+\beta_{1} L N P D B_{i t}+\beta_{2} L N P D B_{j t} \\
& +\beta_{3} \quad L N J A R A K_{i j}+B A H A S A_{i j}+ \\
& \text { SEJARAH }{ }_{i j}+\varepsilon_{i j t}
\end{aligned}
$$

dimana:

$\begin{aligned} \alpha_{0}= & \text { Intersep } \\ \beta_{1}-\beta_{5}= & \text { Koefisien variabel independen } \\ \operatorname{LNCMN}_{i j t}= & \text { Nilai impor jasa } \\ & \text { telekomunikasi negara } \\ & \mathrm{i} \text { dari negara } \mathrm{j} \text { (persen) } \\ = & \text { PDB riil negara importir } \\ & \text { (persen) } \\ \text { NNPDB }_{i t}= & \text { PDB riil negara eksportir } \\ & \text { (persen) } \\ \operatorname{LNPDB}_{j t}= & \text { Jarak geografis antarnegara } \\ & \text { (kilometer) } \\ \operatorname{LNJARAK}_{i j}= & \text { Kesamaan bahasa yang } \\ & \text { digunakan antar negara (nilai } \\ & \text { "1" jika kedua negara } \\ & \text { menggunakan bahasa yang } \\ & \text { sama dan "0" jika kedua } \\ & \text { negara tidak menggunakan } \\ & \text { bahasa yang sama) }\end{aligned}$

SEJARAH $H_{i j} \quad=$ Kesamaan sejarah kolonial antarnegara (nilai "1" jika kedua negara menggunakan sejarah kolonial yang sama dan " 0 " jika kedua negara tidak menggunakan sejarah kolonial yang sama)

Hasil dari estimasi persamaan gravity model menjadi parameter yang digunakan dalam melihat aliran perdagangan potensial antar negara yang berupa the fitted trade flow. Callaghan dan Uprasen (2008) menyatakan perbedaan aliran perdagangan potensial dan aktual menunjukan indikasi adanya hambatan nontarif yang berlaku (tarif equivalent) NTBs. Rumusan hambatan nontarif secara umum yaitu:

$$
\left(T_{i j}-1\right)=\left(\frac{X a i j-X p i j}{X a b-X p b}\right)^{-1 / e}-1
$$

Keterangan :

$\left(T_{i j}-1\right)=$ Hambatan nontarif negara yang diberlakukan negara i kepada negara $\mathrm{j}$

Xaij = Nilai impor aktual negara $\mathrm{i}$ dari negara $\mathrm{j}$ (US\$)

Xpij = Nilai impor potensial negara $\mathrm{i}$ dari negara j (US\$)

$\mathrm{Xab}=$ Nilai impor aktual negara benchmark (US\$)

$\mathrm{Xpb}=$ Nilai impor potensial negara benchmark (US\$)

e $\quad=$ Elastisitas subtitusi sektor jasa yang diperoleh hasil penelitian Park (2002) dan menunjukan elastisitas subtitusi bernilai sebesar 5.6

\section{HASIL DAN PEMBAHASAN Gambaran Umum}

Nilai impor jasa telekomunikasi dalam rentang waktu 2001, 2004, 2007, dan 2011 mengalami peningkatan di setiap tahunnya, hanya di periode waktu tertentu mengalami penurunan. Amerika Serikat merupakan negara importir jasa telekomunikasi terbesar di setiap tahunnya diantara negara APEC lainnya. Impor jasa telekomunikasi USA meningkat dari tahun 2001 sebesar US\$ 1573.39 juta menjadi US\$ 2361.03 juta pada tahun 2004 dan tahun 2007 menjadi sebesar US\$ 4515.15 juta, sedangkan pada tahun 2011 mengalami penurunan menjadi US\$ 3923.99 juta. Disisi lain, Peru memiliki 
nilai impor jasa telekomunikasi terkecil pada tahun 2004 dengan US\$22.69 juta, tahun 2007 dengan US\$ 32.03 juta dan tahun 2011 US\$ 48.17 juta.

Perkembangan PDB rill di negara APEC mengalami peningkatan pada tahun 2001, 2002, 2004 dan 2011. Negara yang memiliki PDB riil terbesar setiap tahunnya ialah USA dengan nilai tertinggi pada tahun 2011 sebesar US\$ 13895 134 miliar. Sedangkan untuk negara yang memiliki PDB riil terkecil setiap tahunnya ialah Vietnam dengan nilai terkecil pada tahun 2001 sebesar US\$ 43355 miliar. Negara APEC sebagai forum kerjasama memiliki anggota yang banyak dan beragam dibandingkan dengan forum kerjasama lainnya sehingga memiliki bahasa dan sejarah kolonial yang beraneka ragam. Bahasa Inggris menjadi bahasa yang sering digunakan oleh negara-negara APEC sebagai Bahasa resmi (official language), bahasa kedua (secondary language), dan bahasa asli (native language). Negara APEC sebagian besar telah mengalami masa penjajahan, kecuali negara China, Jepang, dan Thailand. Negara APEC yang merupakan jajahan kolonial Inggris seperti Australia, Malaysia, Selandia Baru, dan Singapura kini disebut sebagai negara persemakmuran Inggris.

Liberalisasi sektor jasa di negara APEC sendiri sudah difokuskan dengan adanya GOS (group on services) dan khusus sektor jasa telekomunikasinya dalam forum APEC TEL WG

(telecommunication working group) yang didasari oleh dokumen GATS yang kemudian di spesifikasikan terhadap masing-masing negara APEC. GATS tetap menjadi pilar utama pengaturan terhadap semua sektor jasa termasuk pada jasa telekomunikasi. Dalam GATS terdapat dua kewajiban yang diterapkan yaitu kewajiban umum, dimana setiap negara harus mengimplementasikannya walaupun belum meliberalisasikan sektor jasa secara keseluruhan dibawah komimtmen yang tercantum dalam dokumen GATS sebagai empat pilar utama yaitu Most Favoured Nation (MFN) yang merupakan perlakuan sama terhadap semua penyedia jasa, akses pasar, perlakuan nasional, dan komitmen tambahan.

Liberalisasi di Indonesia dalam hal sektor jasa telekomunikasi diawali dengan penandatanganan dokumen GATS pada tahun 1994 sehingga mendorong Indonesia untuk meningkatkan liberalisasi dalam perdagangan jasa. Liberalisasi dimulai melalui penyetujuan WTO Basic Telecommunication Agreement dimana ijin bagi investor untuk menanamkan sahamnya di Indonesia maksimal sebesar 35 persen. Pada tanggal 21 Juli 2006 Indonesia terakhir kali mengajukan Schedule of Commitment (SoC) berdasarkan negosiasi GATS untuk dapat mencapai liberalisasi yang lebih progresif.

Tabel 1. Hasil estimasi gravity model

\begin{tabular}{ccc}
\hline Variable & Coefficient & Prob. \\
\hline LNPDBi & $0.6995^{*}$ & 0.0000 \\
LNPDBj & $0.6811^{*}$ & 0.0000 \\
LNJARAKIJ & $-0.2064^{*}$ & 0.0001 \\
BAHASAIJ & $0.6210^{*}$ & 0.0000 \\
SEJARAHIJ & $0.6438^{* *}$ & 0.0359 \\
C & $-14.5167^{*}$ & 0.0000 \\
R-Squared & & 0.4419 \\
Adjusted R-Squared & & 0.4398 \\
Prob (F-statistic) & & 0.0000 \\
Durbin-Watson Stat & & 1.8933 \\
Sum squared resid (weighted) & & 1106.2190 \\
Sum squared resid (unweighted) & & 1741.9150 \\
**signifikan pada taraf ntara 5 persen & &
\end{tabular}




\section{Gravity Model}

Hasil uji Breusch Pagan bernilai 0.000 lebih kecil dari alpha $(\alpha) 5$ persen, sehingga dapat diambil keputusan untuk menolak $\mathrm{H}_{0}$ yang berarti model yang digunakan dalam penelitian ini adalah Random Effect Model (REM). Hasil estimasi gravity model untuk faktor-faktor yang memengaruhi impor jasa telekomunikasi pada tahun 2001-2011 ditunjukan pada Tabel 1.

Hasil estimasi pada gravity model memiliki nilai koefisien determinasi ( $R$-Squared) sebesar 0.4419 , seperti yang ditunjukan pada Tabel 6 . Hal ini menunjukan bahwa sebesar 44.19 persen nilai impor jasa telekomunikasi dari negara APEC dapat dijelaskan oleh variabel independen (PDBi, PDBj, JARAKij, BAHASAij, dan SEJARAHij) di dalam model sedangkan sisanya dijelaskan oleh peubah lain di luar model. Nilai probabilitas (F-statistic) pada hasil estimasi sebesar 0.0000 lebih kecil dari taraf nyata lima persen, maka pada tingkat kepercayaan 99 persen, variabel PDB riil negara importir, PDB riil negara eksportir, jarak geografis, dummy bahasa, dan dummy sejarah kolonial berpengaruh signifikan terhadap nilai impor sektor jasa telekomunikasi negara APEC.

PDB riil negara APEC menunjukan sisi permintaan (demand side) PDB riil negara importir naik sebesar satu persen maka akan meningkatkan nilai impor jasa telekomunikasi diantara negara APEC sebesar 0.6995 persen (ceteris paribus). Variabel PDB riil negara eksportir yang menunjukan dari sisi penawaran (supply side) bahwa setiap kenaikan sebesar 1 persennya maka akan meningkatkan nilai impor jasa telekomunikasi diantara negara APEC sebesar 0.6811 persen (ceteris paribus). Hal ini mengindikasi bahwa apabila pendapatan suatu negara yang semakin tinggi maka akan mendorong kapasitas berproduksi yang lebih besar sehingga meningkatkan aktivitas ekspor jasa telekomunikasi.

Variabel jarak geografis antar kedua negara dalam hasil estimasi penelitian ini berpengaruh negatif terhadap nilai impor jasa telekomunikasi negara APEC dengan nilai sebesar 0.2064 persen. Hasil estimasi penelitian ini menunjukan bahwa peningkatan jarak geografis antar kedua negara sebesar 1 persen, maka akan menurunkan nilai impor jasa telekomunikasi sebesar 0.2064 persen (ceteris paribus). Hal ini menunjukkan semakin jauh jarak geografis antar negara, maka akan menurunkan nilai perdagangan khususnya dalam penelitian ini aktivitas impor.

Variabel dummy yang menunjukan kesamaan bahasa yang digunakan antar negara APEC memiliki hasil yang signifikan positif terhadap nilai impor jasa telekomunikasi dengan nilai 0.621 persen. Hal ini menunjukkan negara yang memiliki kesamaan bahasa yang digunakan memiliki nilai impor jasa telekomunikasi 0.621 kali lebih besar dibandingkan negara lain yang tidak memiliki kesamaan bahasa. Variabel dummy terakhir yaitu kesamaan sejarah kolonial antar negara APEC yang menunjukan hasil berpengaruh signifikan dan positif terhadap nilai impor jasa telekomunikasi dengan nilai 0.6348 persen. Hal ini menunjukan kedua negara dengan kesamaan sejarah kolonial memiliki nilai impor jasa telekomunikasi yang lebih besar 0.6348 kali dibandingkan negara yang tidak memiliki sejarah kolonial yang sama.

\section{Estimasi Ekuivalen Tarif}

Hasil perhitungan gravity model menjadi acuan dilakukannya estimasi ekuivalen tarif yang menggambarkan perdagangan potensial. Perhitungan tarif impor pada penelitian ini menggunakan nilai impor benchmark berupa nilai perdagangan aktual jasa telekomunikasi antar negara yang paling besar. Nilai impor jasa telekomunikasi aktual paling besar pada penelitian ini adalah USA yang berasal dari Kanada. Pemilihan benchmark dengan metode ini secara relevan menunjukan bahwa aliran perdagangan yang lancar dan hambatannya relatif kecil dibuktikan dengan besarnya nilai impor jasa aktual dari negara tersebut. Hasil perhitungan ekuivalen tarif impor jasa telekomunikasi dapat dilihat pada Lampiran 2, dengan rentang antara 0 hingga 139.55 persen. Adapun hasil perhitungan ekuivalen tarif pada negara benchmark yaitu USA yang berasal dari Kanada adalah sebesar 0.00 persen. Hal ini menunjukan hambatan yang rendah dengan kecilnya ekuivalen tarif impor jasa telekomunikasi, sehingga nilai impor jasa telekomunikasi USA memilki nilai impor jasa 
telekomunikasi yang besar dari setiap negara APEC seperti pada Lampiran 1.

Berdasarkan hasil perhitungan negara yang menerapkan ekuivalen terbesar adalah Meksiko terhadap jasa telekomunikasi yang berasal dari Jepang dengan nilai mencapai 139.55 persen. Secara rata-rata Meksiko juga sebagai negara yang menerapkan ekuivalen tarif paling besar terhadap jasa telekomunikasi dari negara-negara APEC dengan rata-rata 71.135 persen. Sedangkan rata-rata ekuivalen terendah dengan banyaknya hasil yang bertanda negatif adalah negara Singapura. Hasil perhitungan ekuivalen tarif diperkuat oleh latar belakang dokumen GATS yang sudah disepakati oleh masingmasing negara. USA yang menerapkan ekuivalen tarif terendah memiliki liberalisasi pada sektor jasa telekomunikasi yang lebih terbuka. Berbeda dengan Meksiko yang menerapkan ekuivalen tarif tertinggi memiliki liberalisasi yang lebih tertutup jika dibandingkan USA pada jasa telekomunikasi. Sehingga hal ini menunjukan alasan akan besar atau kecilnya ekuivalen yang diterapkan oleh masing-masing negara sesuai dengan dokumen GATS yang diberlakukan. Sedangkan dalam penelitian ini perhitungan tarif ekuivalen yang dimiliki Indonesia menunjukan nilai positif dari keseluruhan negara APEC terhadap jasa telekomunikasi dengan rata-rata 18.366 persen. Dalam hal keterbukaan jasa telekomunikasi Indonesia masih menerapkan hambatan-hambatan khususnya pada modes of supply dalam dokumen GATS pada mode 3 (commercial presence) dan mode 4 (presence of natural) adanya hambatan berupa perizinan tertentu yang berlaku untuk akses pasar dan perlakuan nasional yang diterapkan.

\section{SIMPULAN DAN SARAN}

\section{Simpulan}

Berdasarkan hasil estimasi gravity model, dapat disimpulkan bahwa faktor-faktor yang signifikan memengaruhi nilai impor jasa telekomunikasi di negara APEC adalah PDB riil, jarak, kesamaan bahasa (common language), dan kesamaan sejarah kolonial (comlang ethno). Hasil estimasi ekuivalen tarif impor untuk jasa telekomunikasi menggunakan metode dengan negara USA dari Kanada sebagai bencmark dengan nilai ekuivalen tarif 0.00 persen. Nilai rata-rata ekuivalen tarif tertinggi adalah negara Meksiko, sedangkan rata-rata terendahnya adalah Singapura. Hasil estimasi ekuivalen tarif memilki nilai rentang 0 hingga 139.55 persen. Sedangkan nilai rata-rata ekuivalen tarif yang diterapkan oleh Indonesia ialah 18.366 persen dan semua hasilnya positif. Jika dibandingkan dengan negara ASEAN lainnya seperti Malaysia, Vietnam dan Singapura nilai ekuivalen tarif Indonesia masih tinggi. Hal ini menunjukan posisi Indonesia dalam perdagangan jasa telekomunikasi belum sepenuhnya terbuka atau full liberalized, namun nilai rata-rata ekuivalen tarif Indonesia masih dibawah rata-rata sehingga hambatan yang diterapkan Indonesia masih lebih rendah dibandingkan negara APEC lainnya.

\section{Saran}

1. PDB Indonesia memiliki koefisien tertinggi. Hal ini sesuai prediksi Hayami dan Godo (2005) bahwa sektor jasa dihasilkan oleh negara yang yang memiliki ekonomi yang maju (dengan ukuran GDP tinggi). Oleh karena itu Indonesia seyogyanya meningkatkan kapasitas produksinya.

2. Berdasarkan hasil analisis grivity model, variabel yang berpengaruh secara positif dan memiliki nilai koefisien tinggi adalah PDB negara APEC. Hal ini menjadi peluang pasar yang potensial bagi Indonesia.

3. Peningkatan efisiensi dalam infrastruktur perdagangan jasa diperlukan untuk mengurangi biaya transportasi yang ditimbulkan dari adanya transaksi perdagangan jasa sehingga jauhnya jarak tidak menjadi penghambat dalam hal perdagangan.

4. Melihat variabel dummy bahasa dan sejarah kolonial yang juga berpengaruh signifikan positif pada perdagangan, maka perlu adanya peningkatan kemampuan penggunaan bahasa asing dan negara Indonesia harus menjalin hubungan baik dengan negara yang memiliki kesamaan latar belakang bekas jajahan

5. Berdasarkan hasil analisis estimasi ekuivalen tarif impor pada jasa telekomunikasi dapat menjadi acuan pemerintah untuk menjadi peluang dalam perdagangan jasa telekomunikasi dengan 
negara APEC yang memang memiliki tarif yang rendah sehingga Indonesia tidak hanya menjadi importir namun juga bisa menjadi eksportir.

\section{DAFTAR PUSTAKA}

Azhari M, Widyastutik. 2016. Determinan dan Ekuivalen Tarif Impor Jasa Finansial dan Asuransi Negara APEC. Bogor (ID) : IPB.

Callaghan BAO, Uprasen U. 2008. Impact of The 5th EU Enlargement on ASEAN. Limerik (IE): University of Limerick.

Hayami Y, Godo Y. 2005. Development Economics from the Poverty to The Wealth of Nation, 3. New York (US): Oxford University Press.

Lee CR, Ure J, Lee CH. Quantifying The Impacts of Structural Reforms in Telecommunications Markets in APEC Economies. APEC Policy Unit.
Park SC. 2002. Measuring Tariff Equivalent in Cross Border Trade in Services. KIEP Working Paper: 02-05.

Sapir A. 1988. International Trade in Telecommunications Services. Chicago (US): University of Chicago Press.

Setiawan S. 2011. Peran Sektor Jasa Dalam Mendorong Pengembangan Usaha Kecil Menengah (UKM) [catatan hasil pertemuan]. APEC SOM 1 Related Meetings.

Tinbergen J. 1962. Shapping the World Economy: Suggestion for an Internasional Economicy policy. New York: Twentieth Century Fund.

[WTO] World Trade Organization. 1994. Schedule of Spesific Commitment.. Generel Agreements on Trade in Services. 